\title{
ANALISIS POTENSI PENERIMAAN PAJAK DAERAH DAN RETRIBUSI DAERAH TERHADAP PENINGKATAN PENDAPATAN ASLI DAERAH (PAD) DI SELURUH KABUPATEN/ KOTA PROVINSI MALUKU UTARA
}

\author{
Riri I.C Lumikis \\ David P.E. Saerang \\ Ventje Ilat
}

(email: riri.lumikis@yahoo.co.id)

\begin{abstract}
Local Taxes and Levies is one source of local revenue that has a very important role in the implementation of regional development in North Maluku province. Therefore, with the increasing realization of the kind of reception is in the formation of local revenue (PAD), will show an increase in local fiscal autonomy, as well as reduce the dependence of local development funding from the central government finances. The type of data used in this research, Quantitative Data is data in the form of numbers or numbers that can be processed or analyzed using mathematical or statistical calculations. The research was conducted at the Bureau of Financial Accounting Section of North Maluku Province which is one of the government agencies. Based on the results of research based on the evaluation of historical data and projections of potential tax revenue projections District / City of North Maluku in the next year will increase $29 \%$ and the revenue potential Retribution District / City of North Maluku in the next year will increase $77 \%$.
\end{abstract}

Keywords: Local Taxes, Levies and Local Revenue (PAD)

\section{PENDAHULUAN}

\subsection{Latar Belakang}

Undang-Undang Nomor 33 Tahun 2004 Tentang Pemerintahan Daerah yang merupakan revisi dari Undang-Undang Nomor 22 Tahun 1999 menyatakan bahwa Daerah Otonom, selanjutnya disebut Daerah adalah kesatuan masyarakat hukum yang mempunyai batas-batas wilayah berwenang mengatur dan mengurus urusan pemerintahan dan kepentingan masyarakat setempat menurut prakarsa sendiri berdasarkan aspirasi masyarakat dalam sistem Negara Kesatuan Republik Indonesia.

Menurut Undang- Undang 33 Tahun 2004 Pendapatan Asli Daerah (PAD) adalah pendapatan yang diperoleh darah yang dipungut berdasarkan peraturan daerah sesuai dengan peraturan perundangundangan. Banyaknya kebutuhan daerah dapat dibiayai oleh Pendapatan Asli Daerah (PAD), maka semakin tinggi pula tingkat kualitas otonomi daerah, juga semakin mandiri dalam bidang keuangan daerahnya. Pelaksanaan otonomi daerah yang dititikberatkan pada Daerah Kabupaten dan Daerah Kota dimulai dengan adanya penyerahan sejumlah kewenangan (urusan) dari pemerintah pusat ke pemerintah daerah yang bersangkutan.

Pemerintah daerah di Provinsi Maluku Utara diperhadapkan dengan keterbatasan pembiayaan pembangunan, dalam menjalankan fungsi pemerintah sebagai pelaksana dan pengawas pembangunan tersebut. Saat ini pemerintah daerah lebih disibukan dengan persoalan terbatasnya Dana Alokasi Umum (DAU) yang di terima, padahal sumber pembiayaan pembangunan dalam nuansa otonomi saat ini bersumber pada (Siahaan,2010:14-15):

1. Pendapatan Asli Daerah (PAD) terdiri dari : Pajak Daerah, Retribusi Daerah, Hasil Pengelolaan Kekayaan yang Dipisahkan, Lain- Lain Pendapatan Asli Daerah (PAD) yang Sah.

2. Dana Perimbangan (UU No. 32 Tahun 2004 dan UU No. 33 Tahun 2004) yang terdiri dari : Bagi Hasil, Dana Alokasi Umum (DAU), Dana Alokasi Khusus (DAK)

3. Lain- Lain Pendapatan Daerah yang Sah

Bagaimana sesungguhnya peranan Potensi penerimaan Pajak Daerah dan Retribusi Terhadap Peningkatan Penerimaan Asli Daerah (PAD) di Kabupaten/ Kota Maluku Utara periode 2010 - 2014 ? 
Penelitian ini mencoba mengkaji permasalahan tersebut berikut menawarkan rekomendasi sebagai solusi dalam pemecahan masalah dimaksud.

\subsection{Rumusan Masalah}

Berdasarkan latar belakang di atas maka yang menjadi masalah dalam penelitian ini adalah:

1. Berapa besar tingkat realisasi Pajak Daerah dan Retribusi Daerah

2. Berapa potensi Pajak Daerah dan Retribusi Daerah untuk Proyeksi Pendapatan Asli Daerah (PAD)

\subsection{Batasan masalah}

Agar pembahasan penelitian dapat mencapai tujuan, maka penelitian menggunakan proyeksi pada penerimaan pajak daerah dan Retribusi Kabupaten/kota di Maluku Utara tahun 2010, 2011, 2012, 2013, dan 2014.

\subsection{Tujuan Penelitian}

Penelitian ini dilaksanakan dengan tujuan:

1. Untuk mengetahui potensi Pajak Daerah dan Retribusi dalam Proyeksi Peningkatan PAD kabupaten/kota di Maluku Utara.

2. Untuk Mengetahui Realisasi Pajak Daerah dan Retribusi Daerah

\subsection{Manfaat Penelitian}

Kegunaan yang diharapkan dari penelitian ini adalah sebagai berikut.

1. Bagi peneliti, sebagai sarana untuk menambah wawasan terutama yang terkait dengan masalah dalam penulisan ini.

2. Bagi Dinas Pendapatan Daerah, sebagai bahan pertimbangan dan masukan di masa yang akan datang untuk lebih mengoptimalkan penerimaan pajak daerah dan Retribusi sebagai salah satu elemen untuk meningkatkan PAD dan belanja daerah Kabupaten/ kota di Maluku Utara.

3. Bagi Fakultas, sebagai sarana pengembangan ilmu pengetahuan dan mengevaluasi sejauh mana sistem pendidikan telah dijalankan sesuai kebutuhan dan kondisi.

4. Bagi pihak lain, sebagai bahan bacaan atau literatur mengenai penerapan Undang-undang Nomor 28 Tahun 2009 terhadap pajak daerah dan retribusi daerah yang juga dapat dijadikan bahan referensi atau masukan tambahan bagi yang membutuhkan dan sebagai sarana untuk penelitian selanjutnya.

\section{TINJAUAN PUSTAKA}

\subsection{Landasan Teori}

\subsubsection{Teori Peacock dan Wiseman}

Teori mereka didasarkan pada suatu analisis penerimaan pengeluaran pemerintah. Pemerintah selalu berusaha memperbesar pengeluarannya dengan mengandalkan memperbesar penerimaan dari pajak, padahal masyarakat tidak menyukai pembayaran pajak yang besar untuk membiayai pengeluaran pemerintah yang semakin besar tersebut. Meningkatnya penerimaan pajak menyebabkan pengeluaran pemerintah juga semakin meningkat. Dalam keadaan normal meningkatnya GNP menyebabkan penerimaan pemerintah yang semakin besar, begitu juga dengan pengeluaran pemerintah menjadi semakin besar.

Peacock dan Wiseman mendasarkan teori mereka pada suatu teori bahwa masyarakat mempunyai suatu tingkat toleransi pajak, yaitu suatu tingkat dimana masyarakat dapat memahami besarnya pungutan pajak yang dibutuhkan oleh pemerintah untuk membiayai pengeluaran pemerintah. Jadi masyarakat menyadari bahwa pemerintah membutuhkan dana untuk membiayai aktivitas pemerintah sehingga mereka mempunyai tingkat kesediaan masyarakat untuk membayar pajak. Tingkat toleransi ini merupakan kendala bagi pemerintah untuk menaikkan pemungutan pajak secara semena-mena.

\subsubsection{Definisi Pajak}


Menurut Mardiasmo (2009:1), pajak adalah iuran rakyat kepada kas Negara berdasarkan UndangUndang (yang dapat dipaksakan) dengan tiada mendapat jasa timbal (kontraprestasi) yang langsung dapat ditunjukkan dan yang digunakan untuk membayar pengeluaran umum. Dari definisi tersebut, dapat disimpulkan bahwa pajak memiliki unsur-unsur:

1. Iuran dari rakyat kepada Negara

2. Berdasarkan Undang-Undang

3. Tanpa jasa timbal atau kontraprestasi dari Negara yang secara langsung dapat ditunjuk.

4. Digunakan untuk membiayai rumah tangga Negara.

\subsubsection{Fungsi Pajak}

Fungsi Pajak, yaitu sebagai berikut.

1. Fungsi Penerimaan (budgeter).

2. Fungsi Mengatur (regulator).

3. Fungsi Stabilitas.

4. Fungsi Redistribusi.

5. Fungsi Demokrasi.

\subsubsection{Pengelompokan Pajak}

Menurut Mardiasmo (2009:5-6), pajak dikelompokkan berdasarkan golongannya, sifatnya, dan menurut lembaga pemungutnya.

1. Menurut Golongannya

1) Pajak langsung,

2) Pajak tidak langsung,

2. Menurut Sifatnya

1) Pajak Subjektif,

2) Pajak Objektif,

3. Menurut Lembaga Pemungutnya

1) Pajak Pusat,

2) Pajak Daerah,

\subsubsection{Pajak Daerah}

Dasar hukum pemungutan pajak daerah dan retribusi daerah adalah Undang-undang Nomor 28 Tahun 2009 tentang Pajak Daerah dan Retribusi Daerah. Dalam Undang-undang tersebut Pasal 1 ayat (10) menjelaskan bahwa: Pajak daerah, yang selanjutnya disebut pajak, adalah kontribusi wajib kepada daerah yang terutang oleh orang pribadi atau badan yang bersifat memaksa berdasarkan Undangundang, dengan tidak mendapatkan imbalan secara langsung dan digunakan untuk keperluan daerah bagi sebesar-besarnya kemakmuran rakyat.

Adapun sumber-sumber penerimaan daerah, yaitu:

1. Pendapatan Asli Daerah (PAD);

2. Dana Perimbangan;

3. Bagi Hasil Pajak dan Bukan Pajak;

4. Dana Alokasi Umum (DAU);

5. Dana Alokasi Khusus (DAK);

6. Pinjaman Daerah (Pembiayaan);

7. Lain-lain penerimaan yang Sah;

8. Hibah; dan

9. Dana darurat lainnya.

\subsubsection{Pembagian Pajak Daerah Berdasarkan UU No. 28 Thn 2009}


Menurut Aziz Samudra (2015: 52- 54) pajak daerah terbagi dua, yaitu Pajak Pusat dan Pajak Daerah. Pajak Pusat adalah pajak-pajak yang dikelola oleh Pemerintah Pusat yang dalam hal ini sebagian dikelola oleh Direktorat Jenderal Pajak - Departemen Keuangan. Sedangkan Pajak Daerah adalah pajakpajak yang dikelola oleh Pemerintah Daerah baik di tingkat Provinsi maupun Kabupaten/ Kota. Pajakpajak yang dipungut oleh pemerintah daerah baik provinsi maupun kabupaten/kota adalah sebagai berikut.

1. Pajak Provinsi terdiri dari:

1) Pajak Kendaraan Bermotor;

2) Bea Balik Nama Kendaraan Bermotor;

3) Pajak Bahan Bakar Kendaraan Bermotor;

4) Pajak Air Permukaan; dan

5) Pajak Rokok.

2. Pajak Kabupaten/Kota terdiri dari:

1) Pajak Hotel;

2) Pajak Restoran;

3) Pajak Hiburan;

4) Pajak Reklame;

5) Pajak Penerangan Jalan;

6) Pajak Mineral Bukan Logam dan Batuan;

7) Pajak Parkir;

8) Pajak Air Tanah;

9) Pajak Sarang Burung Walet;

10) Pajak Bumi dan Bangunan Perdesaan dan Perkotaan; dan

11) Bea Perolehan Hak Atas Tanah dan Bangunan (BPHTB).

\subsubsection{Pendapatan Asli Daerah (PAD)}

Menurut Undang- Undang 33 Tahun 2004, Pendapatan Asli Daerah (PAD) adalah pendapatan yang diperoleh daerah yang dipungut berdasarkan peraturan daerah sesuai dengan peraturan perundangundangan. Menurut Undang-undang Nomor 28 Tahun 2009 pengertian Pendapatan Asli Daerah adalah penerimaan yang diperoleh didaerah dari sumber-sumber dalam wilayahnya sendiri yang dipungut berdasarkan peraturan daerah sesuai dengan peraturan perundang-undangan yang berlaku. Berdasarkan pengertian tersebut di atas maka pendapatan asli daerah adalah pendapatan daerah yang sumbersumber pendapatannya berasal dari penggalian atau pungutan daerah, sedangkan besar kecilnya pendapatan daerah sangat ditentukan oleh potensi daerah, keintensifan aparat pemungut pajaknya dan faktor-faktor yang mendukungnya. Pendapatan daerah terdiri dari:

1. Hasil Pajak Daerah;

2. Hasil Retribusi Daerah;

3. Hasil perusahaan milik daerah dan hasil pengelolaan kekayaan daerah yang dipisahkan; dan

4. Lain-lain pendapatan asli daerah lainnya yang sah.

\subsubsection{Retribusi Daerah}

Undang-undang Nomor 34 Tahun 2000 Pasal 18 ayat 1 menentukan bahwa objek retribusi adalah berbagai jenis jasa tertentu yang disediakan oleh pemerintah daerah. Menurut Undang-undang Nomor 28 Tahun 2009 objek retribusi terdiri dari tiga kelompok jasa antara lain:

1. Jasa Umum.

1) Retribusi pelayanan kesehatan

2) Retribusi pelayanan persampahan/ kebersihan

3) Retribusi penggantian biaya cetak kartu tanda penduduk dan akta catatan sipil

4) Retribusi pelayanan pemakaman dan pengabuan mayat

5) Retribusi pelayanan parkir di tepi jalan umum

6) Retribusi pelayanan pasar

7) Retribusi pengujian kendaraan bermotor 
8) Retribusi pemeriksaan alat pemadaman kebakaran

9) Retribusi penggantian biaya cetak peta

10) Retribusi penyediaan dan atau penyedotan kakus

11) Retribusi pengolahan limbah cair

12) Retribusi pelayanan tera/tera ulang

13) Retribusi pelayanan pendidikan

14) Retribusi pengendalian menara telekomunikasi

2. Jasa Usaha,

1) Retribusi pemakaian kekayaan daerah

2) Retribusi pasar grosir dan atau pertokoan

3) Retribusi tempat pelelangan

4) Retribusi terminal

5) Retribusi tempat khusus parkir

6) Retribusi tempat penginapan/ pesanggrahan/ villa

7) Retribusi rumah potong hewan

8) Retribusi pelayanan kepelabuhan

9) Retribusi tempat rekreasi dan olahraga

10) Retribusi penyeberangan di air

11) Retribusi penjualan produksi usaha daerah

3. Perizinan Tertentu,

1) Retribusi izin mendirikan bangunan

2) Retribusi izin tempat penjualan minuman beralkohol

3) Retribusi izin gangguan

4) Retribusi izin trayek

5) Retribusi izin usaha perikanan

\section{KERANGKA KONSEPTUAL}

\subsubsection{Kerangka Konseptual}

Kerangka Konseptual adalah suatu hubungan atau kaitan antara konsep satu terhadap konsep lainnya dari masalah yang ingin diteliti.

Gambar 3.1 Kerangka Konseptual

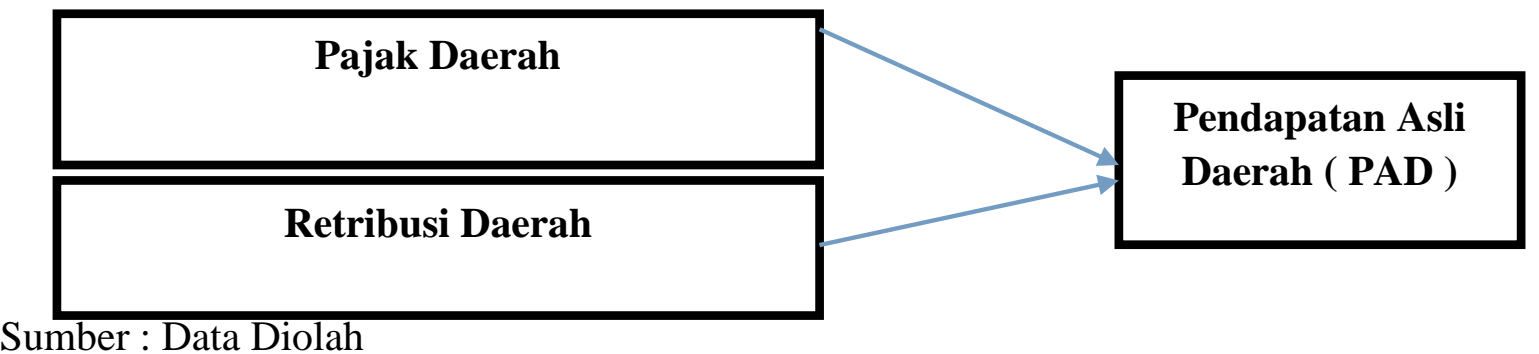

\section{METODE PENELITIAN \\ 4.1 Jenis Data dan Sumber Data}

Adapun jenis data yang digunakan dalam penelitian ini yaitu: Data Kuantitatif, yaitu data yang berbentuk angka atau bilangan sehingga dapat diolah atau dianalisis menggunakan teknik perhitungan matematika atau statistika.

Sumber data yang digunakan dalam penelitian ini yaitu: data primer yaitu data yang diperoleh langsung dari hasil pengamatan (observasi) di lokasi penelitian dan wawancara dengan pihak-pihak yang berkepentingan; dan data sekunder yaitu data yang diperoleh dari pihak lain secara kualitatif yang mempunyai relevansi dengan masalah dalam penulisan ini.

\subsection{Populasi dan Teknik Pengambilan Sampel}


Populasi dalam penelitian ini adalah APBD Pemerintahan Provinsi Maluku Utara. Sampel adalah bagian dari jumlah dan karakteristik yang dimiliki oleh populasi tersebut dan sampel yang diambil dari populasi diharapkan betul representatif atau mewakili (Sugiyono, 2004). Sampel yang diambil menggunakan data runtun waktu (time series) APBD Pemerintahan Provinsi Maluku Utara selama 5 tahun yaitu 2010 - 2014. Objek yang diteliti adalah hasil laporan keuangan Provinsi Maluku Utara tentang Pajak Daerah, Retribusi Daerah dan Pendapatan Asli Daerah (PAD) .

\subsection{Lokasi dan Waktu Penelitian}

Obyek penelitian ini adalah Biro Keuangan Bagian Pembukuan Provinsi Maluku Utara yang merupakan salah satu instansi pemerintah. Penelitian ini dilaksanakan pada Biro Keuangan Bagian Pembukuan Provinsi Maluku Utara. Waktu penelitian yang dilakukan di Biro Keuangan Bagian Pembukuan Provinsi Maluku Utara antara 20 sampai 30 hari.

\subsection{Teknik Pengumpulan Data}

Teknik pengumpulan data yang digunakan dalam penelitian ini adalah sebagai berikut.

1. Studi Kepustakaan

2. Studi Lapang. Teknik yang digunakan untuk memperoleh data dengan melaksanakan studi lapang adalah sebagai berikut.
a. Observasi/Pengamatan
b. Interview/Wawancara
c. Dokumentasi

\subsection{Analisis Data}

Dalam penelitian ini menggunakan analisis sebagai berikut:

1. Analisis Komparatif

2. Analisis Data Historis yang bersifat efektif dan efisien Menghitung kenaikan realisasi tiap tahun

$\begin{array}{lll}\text { Keterangan : } & \\ \mathrm{TK} & = & \begin{array}{l}\text { Penerimaan pajak daerah/ retribusi daerah Tahun } \\ \text { yang bersangkutan }\end{array} \\ \mathrm{N}_{(\mathrm{t})} & =\begin{array}{l}\text { Data realisasi/penerimaan pajak daerah/ retribusi } \\ \text { daerah tahun bersangkutan }\end{array} \\ \mathrm{N}_{(\mathrm{t}-1)}= & \begin{array}{l}\text { Data realisasi/ penerimaan pajak daerah/ retribusi } \\ \text { daerah tahun sebelumnya. }\end{array}\end{array}$

Menghitung rata-rata tingkat kenaikan realisasi penerimaan pajak daerah dan retribusi daerah Kabupaten/ Kota Maluku Utara.

Keterangan :

$\begin{array}{lll}\times \mathrm{TK} & = & \text { Rata- rata tingkat kenaikan realisasi } \\ \sum_{\mathrm{NK}} & = & \text { Jumlah kenaikan realisasi } \\ \mathrm{N} & = & \text { Jumlah Tahun }\end{array}$

Menghitung Proyeksi Penerimaan pajak daerah dan retribusi daerah dengan menggunakan cara :

$\operatorname{Pr}_{(\mathrm{t})} \quad=\quad\{$ TKR + Kenaikan Tarif $\left.)+100 \%\right\} \times \mathrm{N}_{(\mathrm{t}-1)}$

Keterangan :

$\operatorname{Pr}_{(\mathrm{t})} \quad=\quad$ Proyeksi penerimaan pajak daerah/ retribusi daerah pada tahun bersangkutan 


$$
\mathrm{N}_{(\mathrm{t}-1)=} \quad \begin{aligned}
& \text { Penerimaan atau realisasi pajak daerah/retribusi } \\
& \text { daerah satu tahun sebelumnya }
\end{aligned}
$$

\section{ANALISIS DAN PEMBAHASAN HASIL PENELITIAN}

\subsection{Gambaran Umum Objek Penelitian}

Maluku Utara adalah salah satu provinsi di Indonesia. Provinsi yang biasa disingkat sebagai "Malut" ini terdiri dari beberapa pulau di Kepulauan Maluku. Ibukota terletak di Sofifi, Kecamatan Oba Utara, sejak 4 Agustus 2010 menggantikan kota terbesarnya, Ternate yang berfungsi sebagai ibukota sementara selama 11 tahun untuk menunggu kesiapan infrastruktur Sofifi. Secara geografis wilayah Provinsi Maluku Utara berada pada posisi koordinat $3^{\circ}$ Lintang Utara sampai $3^{\circ}$ Lintang Selatan dan $124^{\circ}$ sampai $129^{\circ}$ Bujur Timur, dengan batas-batas wilayah sebagai berikut:
a. Sebelah Timur berbatasan dengan Laut Halmahera
b. Sebelah Barat berbatasan dengan Laut Maluku
c. Sebelah Utara berbatasan dengan Samudera Pasifik
d. Sebelah Selatan berbatasan dengan Laut Seram (Maluku)

Tabel 5.1 Kabupaten/ Kota Maluku Utara

\begin{tabular}{|l|l|l|}
\hline No & \multicolumn{1}{|c|}{ Kabupaten/ Kota } & \multicolumn{1}{|c|}{ Ibu Kota/Kabupaten } \\
\hline 1 & Kabupaten Halmahera Barat & Jailolo \\
\hline 2 & Kabupaten Halmahera Tengah & Weda \\
\hline 3 & Kabupaten Halmahera Utara & Tobelo \\
\hline 4 & Kabupaten Halmahera Selatan & Labuha \\
\hline 5 & Kabupaten Halmahera Timur & Maba \\
\hline 6 & Kabupaten Kepulauan Sula & Sanana \\
\hline 7 & Kabupaten Pulau Morotai & Daruba \\
\hline 8 & Kabupaten Pulau Taliabu & Bopong \\
\hline 9 & Kota Ternate & Ternate \\
\hline 10 & Kota Tidore Kepulauan & Soasiu \\
\hline
\end{tabular}

Sumber : Biro Keuangan Provinsi Maluku Utara

Total luas wilayah Provinsi Maluku Utara mencapai 140.255,32 $\mathrm{km}^{2}$. Sebagian besar merupakan wilayah perairan laut, yaitu seluas $106.977,32 \mathrm{~km}^{2}(76,27 \%)$ sisanya seluas $33.278 \mathrm{~km}^{2}(23,73 \%)$ adalah daratan dengan gugusan pulau-pulau yang satu dengan pulau lainnya dipisahkan oleh laut. Pulau terbesar di Provinsi Maluku Utara adalah Pulau Halmahera. Pulau Ternate dan Pulau Tidore, meski berwilayah lebih kecil, tetapi merupakan dua pulau yang secara historis memiliki makna politik yang penting. Kekayaan sumber daya alam yang dimiliki provinsi ini, berupa hasil tambang, hasil hutan, hasil laut, perkebunan. Maluku Utara setelah dimekarkan sebagai wilayah dengan karakteristik kepulauan, Provinsi Maluku Utara membutuhkan cara tersendiri dalam mendesain arah pengembangan wilayahnya. Keunikan dan kekayaan sumberdaya alam yang besar dengan fisik wilayah yang luas dan dipisahkan oleh pulaupulau besar dan kecil, menyebabkan pentingnya pemekaran wilayah guna mengoptimalkan pemanfaatan dan pengelolaan sumberdaya yang dimilikinya melalui kegiatan pembangunan daerah. 
Gambar 5.1 Struktur Bagian Keuangan Pemerintah Provinsi Maluku Utara

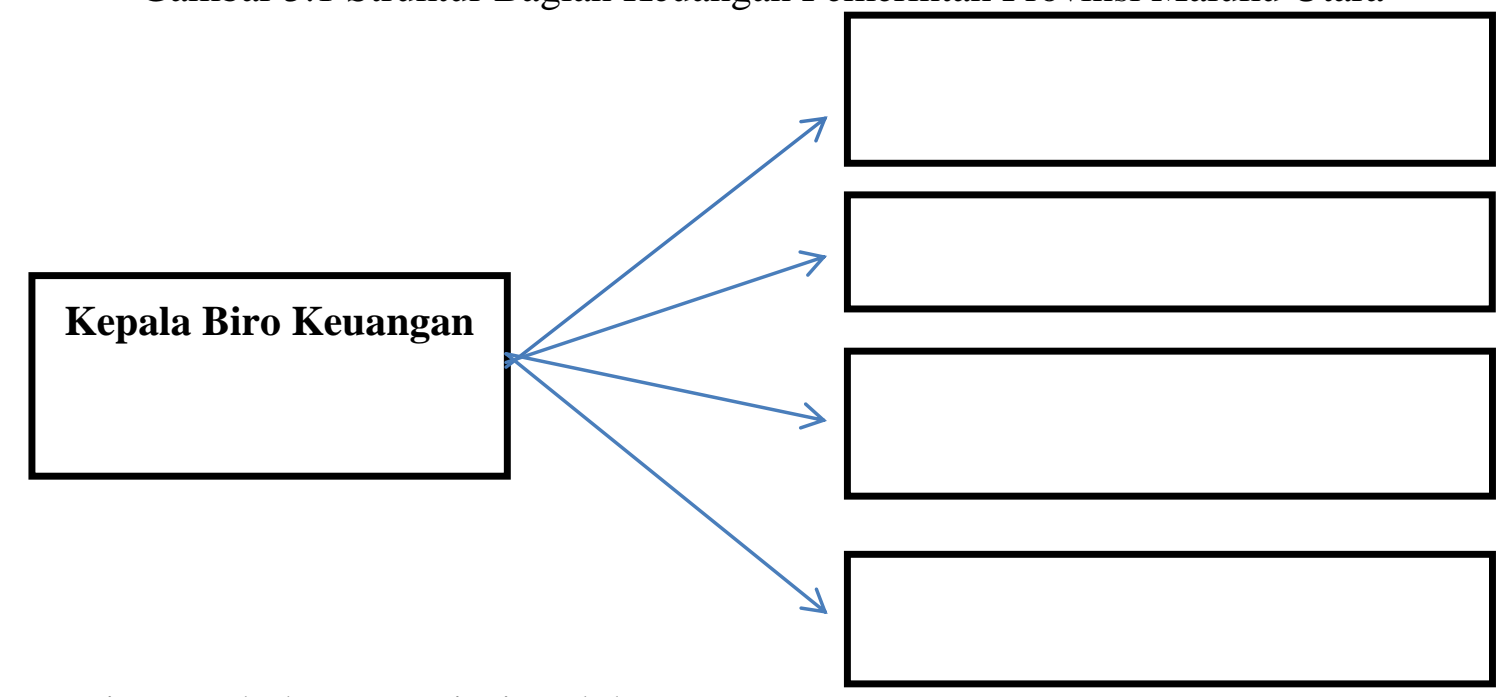

Sumber : Bagian Pembukuan Provinsi Maluku Utara

\subsection{Hasil Penelitian}

\begin{tabular}{|} 
Tabel 5.2 Penerimaan Pajak Daerah Provinsi Maluku Utara Tahun 2010-2014 \\
\begin{tabular}{|c|c|r|r|c|}
\hline No & $\begin{array}{c}\text { Tahun } \\
\text { Anggaran }\end{array}$ & Target & Realisasi & Presentase \\
\hline 1 & 2010 & $54.863 .038 .700,00$ & $53.216 .442 .961,00$ & $97 \%$ \\
\hline 2 & 2011 & $71.740 .514 .259,00$ & $76.615 .643 .887,00$ & $106,80 \%$ \\
\hline 3 & 2012 & $85.430 .016 .000,00$ & $91.735 .154 .190,00$ & $107 \%$ \\
\hline 4 & 2013 & $171.723 .702 .000,00$ & $137.782 .857 .045,00$ & $80,24 \%$ \\
\hline 5 & 2014 & $188.637 .523 .000,00$ & $145.451 .711 .781,00$ & $77,11 \%$ \\
\hline
\end{tabular}
\end{tabular}

Sumber : Biro Keuangan Provinsi Maluku Utara

Tabel 5.3 Penerimaan Retribusi Daerah Provinsi Maluku Utara Tahun 2010-2014

\begin{tabular}{|c|c|r|r|c|}
\hline No & $\begin{array}{c}\text { Tahun } \\
\text { Anggaran }\end{array}$ & \multicolumn{1}{c|}{ Target } & Realisasi & Presentase \\
\hline 1 & 2010 & $10.863 .038 .700,00$ & $8.506 .382 .598,00$ & $78 \%$ \\
\hline 2 & 2011 & $14.786 .167 .195,00$ & $3.987 .006 .632,00$ & $26,96 \%$ \\
\hline 3 & 2012 & $7.525 .000 .000,00$ & $7.201 .988 .812,00$ & $96 \%$ \\
\hline 4 & 2013 & $43.367 .707 .000,00$ & $16.604 .420 .730,00$ & $38,29 \%$ \\
\hline 5 & 2014 & $43.414 .368 .000,00$ & $41.872 .807 .132,00$ & $96,45 \%$ \\
\hline
\end{tabular}

Sumber : Biro Keuangan Provinsi Maluku Utara

Tabel 5.4 Penerimaan Pendapatan Asli Daerah (PAD) Provinsi Maluku Utara Tahun 2010-2014

\begin{tabular}{|c|c|r|r|c|}
\hline No & $\begin{array}{c}\text { Tahun } \\
\text { Anggaran }\end{array}$ & \multicolumn{1}{c|}{ Target } & Realisasi & Presentase \\
\hline 1 & 2010 & $80.532 .261 .205,00$ & $76.897 .535 .120,43$ & $95 \%$ \\
\hline 2 & 2011 & $90.166 .216 .454,00$ & $84.773 .698 .195,70$ & $94,02 \%$ \\
\hline 3 & 2012 & $124.627 .336 .000,00$ & $115.905 .322 .981,68$ & $93 \%$ \\
\hline 4 & 2013 & $237.439 .729 .000,00$ & $165.886 .907 .831,52$ & $69,86 \%$ \\
\hline 5 & 2014 & $255.097 .840 .000,00$ & $203.266 .619 .376,92$ & $79,68 \%$ \\
\hline
\end{tabular}

Sumber : Biro Keuangan Provinsi Maluku Utara 


\subsection{Analisis Data dan Pembahasan}

\subsubsection{Potensi Penerimaan Pajak Daerah Kabupaten/Kota Maluku Utara}

Berdasarkan hasil penelitian dan data yang telah disajikan diatas untuk selanjutnya penulis akan menyajikan hasil Penerimaan Pajak Daerah dengan mengevaluasi data historis realisasi Pajak Daerah Kabupaten/Kota Maluku Utara.

Tabel 5.9 Data Pertumbuhan Pajak Daerah Kabupaten/Kota Maluku Utara Tahun 2010 - 2014

\begin{tabular}{|c|r|c|c|}
\hline Tahun & $\begin{array}{c}\text { Realisasi Pajak } \\
\text { Daerah }\end{array}$ & $\begin{array}{c}\text { Growth/ } \\
\text { Pertumbuhan (Rp) }\end{array}$ & (\%) \\
\hline 2010 & $53.216 .442 .961,00$ & - & - \\
\hline 2011 & $76.615 .643 .887,00$ & $23.399 .200 .926,00$ & $43 \%$ \\
\hline 2012 & $91.735 .154 .190,00$ & $15.119 .510 .303,00$ & $19 \%$ \\
\hline 2013 & $137.782 .857 .045,00$ & $46.047 .702 .855,00$ & $50 \%$ \\
\hline 2014 & $145.451 .711 .781,00$ & $7.668 .854 .736,00$ & $5 \%$ \\
\hline
\end{tabular}

Sumber : Data Diolah

Dari perhitungan diatas, diketahui bahwa realisasi pertumbuhan penerimaan Pajak Daerah yaitu kenaikan 43\% pada tahun 2011. Kemudian mengalami penurunan 19\% pada tahun 2012. Pada tahun 2013 mengalami kenaikan 50\%. Sedangkan pada tahun 2014 mengalami penurunan $5 \%$.

Menghitung rata-rata tingkat pertumbuhan real (TKR)

TK

$$
=-=29 \%
$$

Jadi rata-rata tingkat kenaikan potensi Pajak Daerah adalah sebesar $29 \%$.

Menghitung proyeksi penerimaan potensi Pajak Daerah tahun- tahun berikutnya:

5.10 Potensi Penerimaan Pajak Daerah

\begin{tabular}{|c|r|r|c|}
\hline Tahun & \multicolumn{1}{|c|}{ Pajak Daerah } & \multicolumn{1}{c|}{ Pertumbuhan } & $\mathbf{( \% )}$ \\
\hline 2010 & $53.216 .442 .961,00$ & - & - \\
\hline 2011 & $76.615 .643 .887,00$ & $23.339 .200 .926,00$ & $43 \%$ \\
\hline 2012 & $91.735 .154 .190,00$ & $15.119 .510 .303,00$ & $19 \%$ \\
\hline 2013 & $137.782 .857 .045,00$ & $46.047 .702 .855,00$ & $50 \%$ \\
\hline 2014 & $145.451 .711 .781,00$ & $7.668 .854 .736,00$ & $5 \%$ \\
\hline 2015 & $187.632 .708 .197,00$ & $42.180 .996 .416,00$ & $29 \%$ \\
\hline 2016 & $242.046 .193 .574,00$ & $54.413 .485 .377,00$ & $29 \%$ \\
\hline 2017 & $312.239 .589 .710,00$ & $70.193 .396 .136,00$ & $29 \%$ \\
\hline 2018 & $402.789 .070 .725,00$ & $90.549 .481 .015,00$ & $29 \%$ \\
\hline
\end{tabular}

Sumber : Data Diolah

Penghitungan Potensi Pajak Daerah tahun-tahun berikutnya :
2015 :
$=187.632 .708 .197,00$
2016 :
$=242.046 .193 .574,00$
2017
$=312.239 .589 .710,00$
2018 :
$=402.789 .070 .725,00$

\subsubsection{Potensi Penerimaan Retribusi Daerah Kabupaten/Kota Maluku Utara}

Berdasarkan hasil penelitian dan data yang telah disajikan diatas untuk selanjutnya penulis akan menyajikan hasil Penerimaan Retribusi Daerah dengan mengevaluasi data historis realisasi Retribusi Daerah Kabupaten/Kota Maluku Utara

Tabel 5.11 Data Pertumbuhan Retribusi Daerah Kabupaten/Kota Maluku Utara 
Tahun $2010-2014$

\begin{tabular}{|c|c|c|c|}
\hline Tahun & $\begin{array}{c}\text { Realisasi Retribusi } \\
\text { Daerah }\end{array}$ & $\begin{array}{c}\text { Growth/ } \\
\text { Pertumbuhan (Rp) }\end{array}$ & $\mathbf{( \% )}$ \\
\hline 2010 & 8.506 .382 .598 & - & - \\
\hline 2011 & 3.987 .006 .632 & $(4.519 .375 .966,00)$ & $-53 \%$ \\
\hline 2012 & 7.201 .988 .812 & $3.214 .982 .180,00$ & $80 \%$ \\
\hline 2013 & 16.604 .420 .730 & $9.402 .431 .918,00$ & $130 \%$ \\
\hline 2014 & 41.872 .807 .132 & $25.268 .386 .402,00$ & $152 \%$ \\
\hline
\end{tabular}

Sumber : Data Diolah

Dari perhitungan diatas, diketahui bahwa realisasi penerimaan Retribusi Daerah yaitu penurunan $-53 \%$ pada tahun 2011. Kemudian mengalami kenaikan $80 \%$ pada tahun 2012. Pada tahun 2013 mengalami kenaikan 130\%. Sedangkan pada tahun 2014 mengalami kenaikan 152\%. Menghitung rata-rata tingkat pertumbuhan real (TKR)

TK

$$
=\quad=77 \%
$$

Jadi rata-rata tingkat kenaikan potensi Retribusi Daerah adalah sebesar 77\%.

Menghitung proyeksi penerimaan potensi Retribusi Daerah tahun- tahun berikutnya:

5.12 Potensi Penerimaan Pajak Daerah

\begin{tabular}{|c|r|r|c|}
\hline Tahun & \multicolumn{1}{|c|}{ Retribusi Daerah } & \multicolumn{1}{c|}{ Pertumbuhan } & (\%) \\
\hline 2010 & $8.506 .382 .598,00$ & - & - \\
\hline 2011 & $3.987 .006 .632,00$ & $(4.519 .375 .966,00)$ & $-53 \%$ \\
\hline 2012 & $7.201 .988 .812,00$ & $3.214 .982 .180,00$ & $80 \%$ \\
\hline 2013 & $16.604 .420 .730,00$ & $9.402 .431 .918,00$ & $130 \%$ \\
\hline 2014 & $41.872 .807 .132,00$ & $25.268 .386 .402,00$ & $152 \%$ \\
\hline 2015 & $74.114 .868 .623,00$ & $32.242 .061 .491,00$ & $77 \%$ \\
\hline 2016 & $131.183 .317 .462,00$ & $57.068 .448 .839,00$ & $77 \%$ \\
\hline 2017 & $232.194 .471 .907,00$ & $101.011 .154 .445,00$ & $77 \%$ \\
\hline 2018 & $410.984 .215 .275,00$ & $178.789 .743 .368,00$ & $77 \%$ \\
\hline
\end{tabular}

Sumber : Data Diolah

Penghitungan Potensi Retribusi Daerah tahun-tahun berikutnya :

$\begin{array}{rlll}2015: & - & =74.114 .868 .623,00 \\ 2016: & - & =131.183 .317 .462,00 \\ 2017: & - & =232.194 .471 .907,00 \\ 2018: & - & =410.984 .215 .275,00\end{array}$

\section{KESIMPULAN DAN SARAN}

\subsection{Kesimpulan}

Berdasarkan hasil penelitian dan pembahasan pada bab sebelumnya, maka dapat diambil kesimpulan sebagai berikut :

1. Perkembangan penerimaan Pajak Daerah dan Retribusi Daerah Kabupaten/Kota Maluku Utara pada tahun 2010 - 2014 cenderung meningkat. Walaupun pada tahun pada tahun 2011 mengalami penurunan pada retribusi.

2. Penerimaan Pajak Daerah Kabupaten/Kota Maluku Utara dalam kurun waktu lima tahun dan tahun 2010 sampai tahun 2014 yaitu pada tahun $2010 \mathrm{Rp} 53.216 .442 .961$, tahun $2011 \mathrm{Rp}$ 76.615.643.887, tahun $2012 \mathrm{Rp}$ 91.735.154.190, tahun $2013 \mathrm{Rp} 137.782 .857 .045$ dan di tahun 2014 Rp 145.451.711.781

3. Penerimaan Retribusi Daerah Kabupaten/Kota Maluku Utara dalam kurun waktu lima tahun dari tahun 2010 sampai tahun 2014 yaitu pada tahun 2010 Rp 8.506.382.598, pada tahun 2011 terjadi 
penurunan menjadi Rp 3.987.006.632, tahun 2012 terjadi kenaikan menjadi Rp 7.201.988.812, tahun 2013 Rp 16.604.420.730, dan tahun 2014 Rp 41.872.807.132.

4. Berdasarkan evaluasi dan proyeksi data historis proyeksi potensi penerimaan Pajak Daerah Kabupaten/Kota Maluku Utara pada tahun berikutnya akan terjadi kenaikan 29\% dan potensi penerimaan Retribusi Daerah Kabupaten/Kota Maluku Utara pada tahun berikutnya akan terjadi kenaikan $77 \%$.

\subsection{Saran}

Berdasarkan hasil penelitian dan pembahasan pada bab sebelumnya, maka dapat diberikan beberapa saran antara lain sebagai berikut :

1. Sosialisasi kepada masyarakat mengenai Pajak Daerah dan Retribusi Daerah harus lebih digalakkan agar terciptanya kesadaran kolektif sehingga masyarakat menjalankan kewajibannya demi meningkatkan penerimaan Pajak Daerah dan Retribusi Daerah Kabupaten/Kota Maluku Utara.

2. Lebih ditingkatkan lagi fungsi kontrol dari pemerintah terhadap instansi terkait demi terciptanya kinerja yang lebih baik lagi sehingga untuk tahun-tahun selanjutnya dapat memberikan hasil dari penerimaan Pajak Daerah dan Retribusi Daerah yang lebih optimal.

3. Pemerintah Kabupaten/Kota Maluku Utara khususnya dinas yang terkait harus mengikuti prosedur yang ada dan lebih tegas lagi terhadap wajib pajak melalui pemberian sangsi hukum yang tegas bagi yang melanggar.

\section{DAFTAR PUSTAKA}

Anggraeni, Dina. 2010. Analisis Pengaruh Penerimaan Pajak Daerah dan Retribusi Daerah Terhadap Peningkatan Pendapatan Asli Daerah (PAD) (Studi Empiris pada Provinsi Bengkulu). Skripsi.

Tidak Dipublikasikan. Jakarta. Universitas Islam Negeri Syarif Hidayatullah.

Halim, Abdul. 2009. Akuntansi Keuangan Daerah. Jakarta. Penerbit Salemba Empat.

http://jikti.bakti.or.id/updates/menakar-pembangunan-ekonomi-maluku-utara

Indrianto, Supono. 2009. Metodologi Penelitian Bisnis Untuk Akuntansi dan Manajemen. Yogyakarta. BPFE

Mahsun, Mohamad. 2007. Akuntansi Sektor Pubik. Yogyakarta. Fakultas Ekonomi UGM.

Mardiasmo. 2009. Perpajakan Edisi Revisi 2009. Yogyakarta. ANDI.

Mardiasmo.2009. Akuntansi Sektor Publik. Yogyakarta. ANDI.

Mawarni, Darmawan, dan Abdullah Syukriy. 2013. Pengaruh Pendapatan Asli Daerah dan Dana Alokasi

Umum Terhadap Belanja Modal Serta Dampak Terhadap Pertumbuhan Ekonomi Daerah (Studi

Pada Kabupaten dan Kota di Aceh). Jurnal Akuntansi Pascasarjana Universitas Syiah Kuala.

Volume 2. Hal $80-90$.

Nugroho, Adi. 2013. Analisis Pengaruh Pajak Daerah dan Retribusi Daerah Terhadap Pendapatan Asli Daerah (PAD) Kabupaten/ Kota di Provinsi Jawa Tengah Periode 2010-2012. Skripsi. Tidak Dipublikasikan. Jawa Tengah. Universitas Dian Nuswantoro.

Purnama, Arif. 2014. Pengaruh Dana Alokasi Umum (DAU), Pendapatan Asli Daerah (PAD), Sisa Lebih Pembiayaan Anggaran (SiLPA), dan Luas Wilayah Terhadap Belanja Modal Pada Kabupaten dan Kota di Jawa Tengah Periode 2012-2013. Skripsi. Tidak Dipublikasikan. Surakarta. Universitas Muhammadiyah Surakarta.

Prasetya, Ferry. 2012. Modul Ekonomi Publik. Malang. Universitasitas Brawijaya.

Riduansyah, Mohammad. 2003. Kontribusi Pajak Daerah dan Retribusi Daerah Terhadap Pendapatan Asli

Daerah (PAD) dan Anggaran Pendapatan dan Belanja Daerah (APBD) Guna Mendukung Pelaksanaan Otonomi Daerah (Studi Kasus Pemerintah Daerah Kota Bogor). Makara, Sosial Humaniora. Volume 7. Hal 49 - 57.

Ruswandi, Rina Rahmawati (2009). Analisis pengaruh pajak daerah terhadap pendapatan asli daerah $(P A D)$ di Kabupaten Sumedang. Skripsi Fakultas Ekonomi dan Manajemen Institut Pertanian Bogor (tidak dipublikasikan).

Samudra, Azhari. 2015. Perpajakan Di Indonesia. Jakarta. PT Rajagrafindo Persada. 
Siahaan, Mariot. 2010. Pajak Daerah dan Retribusi Daerah. Jakarta. PT Rajagrafindo Persada. Tambunan, Tulus. 2009. Perekonomian Indonesia. Bogor. Ghalia Indonesia

Undang-Undang Nomor 28 Tahun 2009 tentang Pajak Daerah dan Retribusi Daerah.

Undang- Undang Nomor 33 Tahun 2004 tentang Perimbangan Keuangan Antara Pemerintah Pusat dan Pemerintah Daerah

Waluyo. 2011. Perpajakan Indonesia Buku 1. Jakarta. Salemba Empat.

Waluyo. 2011. Perpajakan Indonesia Buku 2. Jakarta. Salemba Empat.

Wirawati Putu dan Kusuma Krisna. 2013. Analisis Pengaruh Penerimaan Pajak Daerah dan Retribusi Daerah Terhadap Peningkatan PAD Se Kabupaten/ Kota di Provinsi Bali. E-Jurnal Akuntansi Universitas Udayana. Hal 574 - 585.

www.djpk.kemenkeu.go.id

www.humasprovmalut.com

www.kemenkeu.go.id

www.pajak.go.id 